\title{
ANALISA NILAI PERUSAHAAN PADA PERUSAHAAN SEKTOR INDUSTRI BARANG KONSUMSI
}

Michelle Vanessa

michelle.vanessa@student.umn.ac.id, Akuntansi, Universitas Multimedia Nusantara

\section{Maria Stefani Osesoga}

maria.stefani@student.umn.ac.id, Akuntansi, Universitas Multimedia Nusantara

\begin{abstract}
Abstrak
Penelitian ini bertujuan untuk mendapatkan bukti empiris mengenai pengaruh profitabilitas $(R O A)$, likuiditas $(C R)$, pertumbuhan perusahaan, dan struktur modal $(D E R)$ terhadap nilai perusahaan $(P B V)$. Nilai perusahaan sangat penting karena mencerminkan kinerja perusahaan yang dapat mempengaruhi persepsi investor terhadap perusahaan. Sampel pada penelitian ini dipilih dengan menggunakan metode purposive sampling dan data sekunder yang dianalisa dengan menggunakan model regresi linier berganda. Hasil penelitian ini adalah profitabilitas, likuiditas, dan struktur modal memiliki pengaruh positif signifikan terhadap nilai perusahaan. Sedangkan pertumbuhan perusahaan memiliki pengaruh negatif signifikan terhadap nilai perusahaan.
\end{abstract}

Kata Kunci : likuiditas, nilai perusahaan, pertumbuhan perusahaan, profitabilitas, struktur modal

\section{ANALYSIS OF FIRM VALUE IN THE CONSUMPTION GOODS INDUSTRY SECTOR}

\begin{abstract}
The purpose of this research is to obtain empirical evidence about the effect of profitability (ROA), liquidity (CR), firm growth, and capital structure (DER), towards firm value (PBV). Firm value is very important because it reflects on the company's performance that can affect on investor's perception towards the company. The sample in this study was selected using the purposive sampling method and secondary data were analyzed using multiple linear regression models. The results of this research are profitability, liquidity, and capital structure have a positive significant effect on firm value. Meanwhile company growth has a negative significant effect on firm value.
\end{abstract}

Keywords: capital structure, firm growth, firm value, liquidity, profitability 


\section{PENDAHULUAN}

Dilansir dari website Bursa Efek Indonesia, kapitalisasi pasar industri manufaktur sektor barang konsumsi (consumer goods) menempati posisi tertinggi kedua setelah industri finance.

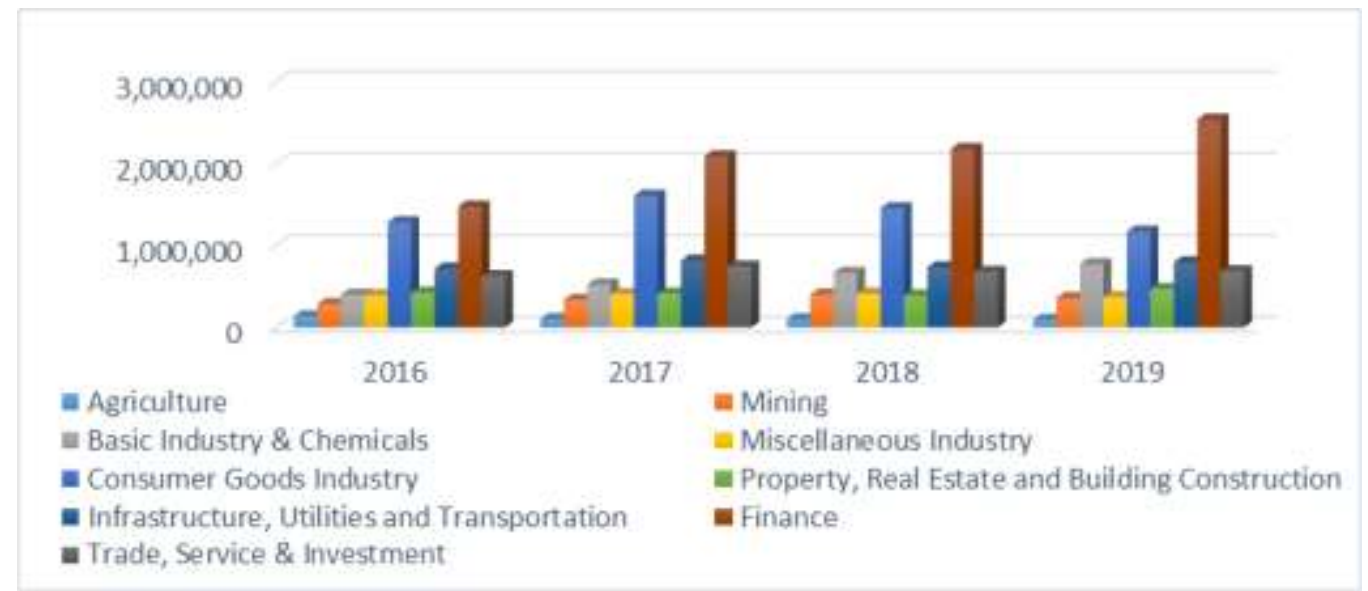

Gambar 1. Data Kapitalisasi Pasar Industri Tahun 2016-2019 (dalam milyar Rupiah) Sumber: Bursa Efek Indonesia (www.idx.co.id)

Berdasarkan Gambar 1, industri manufaktur sektor barang konsumsi menempati posisi kedua tertinggi dalam kapitalisasi pasar di bursa, yang berarti industri manufaktur sektor konsumsi ini masih memiliki peranan signifikan terhadap pasar modal. Kinerja industri manufaktur sektor barang konsumsi yang aktif ini menunjukkan upayanya meningkatkan daya saing melalui ekspansi. Untuk membantu upaya ekspansi tersebut diperlukan bantuan dari para investor dan juga kreditur dalam hal memenuhi kebutuhan pendanaan bagi perusahaanperusahaan sektor barang konsumsi. Para investor dan kreditur dalam mengambil keputusan terkait penanaman modal dan pemberian kredit dapat menggunakan nilai perusahaan sebagai salah satu dasar pengambilan keputusan.

Nilai perusahaan merupakan persepsi investor terhadap tingkat keberhasilan perusahaan yang sering dikaitkan dengan penawaran dan permintaan yang mempengaruhi pergerakan harga di pasar modal. Harga saham yang tinggi membuat nilai perusahaan juga tinggi (Nugraha et al., 2018). Mengoptimalkan nilai perusahaan dinilai lebih tepat sebagai tujuan perusahaan karena berarti mengoptimalkan nilai sekarang dari semua keuntungan yang akan diterima oleh pemegang saham pada masa mendatang atau berorientasi jangka panjang (Khoirunnisa et al., 2018). Dalam penelitian ini proksi yang digunakan adalah Price Book Value $(P B V)$. $P B V$ merupakan perbandingan antara harga pasar per lembar saham dengan nilai buku per lembar saham (Suwardika dan Mustanda, 2017). Menurut Khoirunnisa et al. (2018), $P B V$ dapat digunakan untuk menilai suatu perusahaan karena $P B V$ dapat menggambarkan jumlah apresiasi investor pada saham berdasarkan nilai buku per lembar sahamnya. $P B V$ yang tinggi membuat pasar akan percaya terhadap prospek perusahaan ke depan (Putra dan Lestari, 2016). Tingginya $P B V$ mencerminkan tingginya harga saham jika dibandingkan dengan nilai buku per lembar saham. Keberhasilan perusahaan menciptakan nilai bagi pemegang saham dilihat dari semakin tinggi harga saham perusahaan. Adanya peluang investasi memberikan sinyal yang positif terhadap perkembangan perusahaan dimasa mendatang, sehingga nilai perusahaan dapat meningkat (Kohar dan Akramunnas, 2017).

$P B V$ yang tinggi membuat pasar akan percaya terhadap prospek perusahaan ke depan (Putra dan Lestari, 2016). Seperti contoh PT Sekar Laut Tbk (SKLT) yang sedang 
memperluas pasar domestik dan ekspor untuk mencapai target pertumbuhan penjualan sebesar $15 \%$ dan pertumbuhan laba sebesar 20\% tahun 2019. Direktur PT Sekar Laut Tbk, John C Gozal, mengatakan, pada 2018 lalu penjualan perseroan tembus Rp1 triliun atau meningkat sebesar 14,3\%. Sedangkan laba bersih perseroan mencapai sebesar Rp32 miliar, mengalami peningkatan dibandingkan tahun 2017 sebesar Rp23 miliar. Selain peningkatan penjualan, peningkatan laba bersih 39\% diatas target yang diperkirakan sebesar 20\% itu juga dikarenakan efisiensi pada beban-beban perusahaan (www.jatim.sindonews.com).

Tabel 1. Data Net Income, Harga Saham, dan PBV SKLT 2016 - 2018

\begin{tabular}{lccc}
\hline & $\mathbf{2 0 1 6}$ & $\mathbf{2 0 1 7}$ & $\mathbf{2 0 1 8}$ \\
\hline $\begin{array}{l}\text { Net Income } \\
\begin{array}{l}\text { Harga Saham (rata- } \\
\text { rata/tahun) }\end{array}\end{array}$ & $\mathrm{Rp} \mathrm{20.646.121.074}$ & $\mathrm{Rp} \mathrm{22.970.715.348}$ & $\mathrm{Rp} \mathrm{31.954.131.252}$ \\
$P B V$ & 0,76 & $\mathrm{Rp} \mathrm{751}$ & $\mathrm{Rp} \mathrm{1.285}$ \\
\hline
\end{tabular}

Sumber : www.idx.co.id dan www.investing.com

Tabel 1 menunjukkan peningkatan laba besih (Net Income), harga saham rata-rata per tahun, dan Price Book Value (PBV) PT Sekar Laut Tbk (SKLT) pada tahun 2016 sampai 2018. Pada tahun 2016, laba bersih PT Sekar Laut Tbk (SKLT) adalah sebesar Rp20.646.121.074 dan tumbuh meningkat sebesar 11,26\% menjadi Rp22.970.715.348 pada tahun 2017. Pada tahun 2018, laba bersih PT Sekar Laut Tbk (SKLT) juga tumbuh meningkat sebesar 39,11\% dari tahun 2017 sehingga menunjukkan angka sebesar Rp31.954.131.252. Rata-rata harga saham per tahun PT Sekar Laut Tbk (SKLT) juga mengalami peningkatan pada tahun 2016 sampai 2018. Rata-rata harga saham per tahun PT Sekar Laut Tbk (SKLT) tahun 2016 adalah sebesar Rp326 dan meningkat sebesar Rp424 menjadi sebesar Rp751 pada tahun 2017. Pada tahun 2018, rata-rata harga saham per tahun PT Sekar Laut Tbk (SKLT) juga mengalami peningkatan sebesar Rp534 dari tahun 2017 sehingga menunjukkan angka sebesar Rp1.285. Tabel 1 juga menunjukkan bahwa Price to Book Value (PBV) PT Sekar Laut Tbk (SKLT) mengalami peningkatan setiap tahunnya. Pada tahun 2016, PBV PT Sekar Laut Tbk (SKLT) sebesar 0,76 dan meningkat di tahun 2017 menjadi sebesar 1,69. Pada tahun 2018, PBV PT Sekar Laut Tbk (SKLT) meningkat 0,93 sehingga menunjukkan angka sebesar 2,62. Meningkatnya $P B V$ PT Sekar Laut Tbk (SKLT) dari tahun 2016-2018 dapat menjadi pertimbangan bagi investor atau kreditur dalam memberikan investasi atau kredit.

Dilansir dari website Sindonews, pada tahun 2018 PT Sekar Laut Tbk berencana mendatangkan mesin baru untuk meningkatkan kapasitas produk, terutama untuk produksi sambal. Saat ini, kapasitas produksi sambal di Sekar Laut mencapai 6.000 ton per tahun dan akan ditambah 3.000 ton per tahun sehingga kedepan kapasitas produksi sambal bisa mencapai 9.000 ton per tahun. Presiden Direktur PT Sekar Laut Tbk, Harry Sunogo mengatakan, perseroan memiliki tiga jenis produk, yakni kerupuk, sambal dan roti. Dari ketiga jenis produk tersebut, pertumbuhan penjualan sambal paling tinggi, yakni mencapai 30\%. Tingginya penjualan sambal ini karena masih mencari pasar-pasar baru. Saat ini, kontribusi sambal dari total penjualan perseroan mencapai $42 \%$. Untuk investasi mesin sambal ini diperkirakan mencapai Rp20 miliar. Dana pembelian mesin berasal dari kas internal dan juga pinjaman bank. Diperolehnya dana pinjaman dari bank tersebut menunjukkan adanya kepercayaan bank terhadap prospek dan kinerja perusahaan yang baik. Hal ini menunjukkan bahwa investor dan kreditur akan berinvestasi dan memberikan kredit terhadap perusahaan yang memiliki nilai perusahaan yang tinggi karena nilai perusahaan yang tinggi akan menunjukkan prospek dan kinerja perusahaan yang baik sehingga meningkatkan kepercayaan pasar terhadap perusahaan tersebut. 
Terdapat banyak faktor yang dapat mempengaruhi nilai perusahaan. Penelitian ini menggunakan empat faktor yaitu profitabilitas, likuiditas, pertumbuhan perusahaan dan struktur modal. Profitabilitas, dalam penelitian ini diukur menggunakan Return on Asset $(R O A)$, merupakan rasio yang menunjukkan kemampuan perusahaan dalam mengelola aset perusahaan untuk menghasilkan laba. Semakin tinggi profitabilitas menunjukkan perusahaan mampu mengelola asetnya untuk menghasilkan laba yang tinggi. Laba yang tinggi akan menarik perhatian para investor untuk membeli saham perusahaan. Tingginya permintaan investor untuk membeli saham perusahaan akan mendorong kenaikan harga saham perusahaan. Naiknya harga saham perusahaan yang melebihi nilai buku perusahaan akan menyebabkan nilai perusahaan yang diproksikan dengan $P B V$ meningkat.

Likuiditas, dalam penelitian ini diukur menggunakan current ratio $(C R)$, merupakan perbandingan antara aset lancar (current asset) dengan utang lancar (current liabilities). Current Ratio yang tinggi menandakan perusahaan memiliki kecukupan dana untuk melunasi utangnya. Hal ini akan menarik perhatian para investor untuk membeli saham perusahaan. Tingginya permintaan investor untuk membeli saham perusahaan akan mendorong kenaikan harga saham perusahaan. Naiknya harga saham perusahaan yang melebihi nilai buku perusahaan akan menyebabkan nilai perusahaan yang diproksikan dengan $P B V$ meningkat.

Seberapa besar pertumbuhan perusahaan dapat diukut dengan membandingkan antara total aset periode sebelumnya dan total aset periode sekarang. Dengan adanya penambahan jumlah aset contohnya seperti mesin, perusahaan mampu meningkatkan kapasitas produksinya sehingga penjualan dan laba perusahaan akan tinggi. Hal ini akan menarik perhatian para investor untuk membeli saham perusahaan. Tingginya permintaan investor untuk membeli saham perusahaan akan mendorong kenaikan harga saham perusahaan. Naiknya harga saham perusahaan yang melebihi nilai buku perusahaan akan menyebabkan nilai perusahaan yang diproksikan dengan $P B V$ meningkat.

Struktur modal adalah perbandingan modal asing (utang) dengan modal sendiri yang merupakan salah satu fungsi dalam pengambilan keputusan mengenai pembelanjaan perusahaan (Putri, 2016). Proksi yang digunakan untuk variabel ini adalah Debt Equity Ratio (DER) dengan membagi total utang dengan total ekuitas perusahaan (Chasanah dan Adhi, 2017). DER yang rendah berarti utang yang dimiliki perusahaan sedikit dan akan menarik perhatian para investor untuk membeli saham perusahaan. Tingginya permintaan investor untuk membeli saham perusahaan akan mendorong kenaikan harga saham perusahaan. Naiknya harga saham perusahaan yang melebihi nilai buku perusahaan akan menyebabkan nilai perusahaan yang diproksikan dengan $P B V$ meningkat.

Penelitian-penelitian sebelumnya yang menunjukkan hasil yang berbeda terkait faktor yang mempengaruhi nilai perusahaan dan pentingnya nilai perusahaan untuk pihak internal dan eksternal perusahaan mendorong peneliti untuk memperoleh bukti empiris mengenai pengaruh positif profitabilitas, likuiditas, struktur modal, dan pengaruh negatif struktur modal terhadap nilai perusahaan.

\section{TINJAUAN PUSTAKA}

\section{Signalling Theory}

Signaling Theory mengemukakan tentang bagaimana seharusnya perusahaan memberikan signal (isyarat) kepada pengguna laporan keuangan (Susanti, 2016). Jika kinerja keuangan yang dilaporkan oleh perusahaan meningkat maka informasi tersebut dapat dikategorikan sebagai sinyal baik karena mengindikasikan kondisi perusahaan yang baik. Sebaliknya jika kinerja keuangan yang dilaporkan menurun maka perusahaan berada dalam kondisi tidak baik sehingga dianggap sebagai sinyal yang jelek (Mudjijah et al., 2019). Tujuan dari teori signal adalah diharapkan akan mempengaruhi keputusan investor untuk berinvestasi sehingga nantinya akan mempengaruhi nilai perusahaan. 


\section{Nilai Perusahaan}

Nilai perusahaan merupakan persepsi investor terhadap tingkat keberhasilan perusahaan yang sering dikaitkan dengan penawaran dan permintaan yang mempengaruhi pergerakan harga di pasar modal (Nugraha et al., 2018). Tujuan utama dari suatu perusahaan yaitu dengan memaksimalisasi nilai perusahaan melalui kemakmuran pemilik perusahaan (pemegang saham) yang ditunjukkan dengan meningkatnya nilai perusahaan yang tercermin dari harga saham perusahaan (Haryadi, 2016). Dalam penelitian ini, nilai perusahaan diproksikan dengan Price Book Value $(P B V)$. Rasio ini merupakan rasio antara harga pasar saham terhadap nilai bukunya (Chasanah dan Adhi, 2017). Menurut Susanti (2016), PBV menggambarkan seberapa besar pasar menghargai nilai buku saham perusahaan.

\section{Profitabilitas}

Profitabilitas adalah tingkat keuntungan bersih yang mampu diraih oleh perusahaan saat menjalankan operasinya (Sudiani dan Darmayanti, 2016). Tingginya profitabilitas menunjukkan efektivitas pengelolaan manajemen perusahaan (Putra dan Lestari, 2016). Tingginya profitabilitas juga dapat menunjukkan prospek perusahaan yang baik kepada para investor karena para investor akan tertarik pada perusahaan yang memiliki profitabilitas yang baik, sehingga adanya peningkatan permintaan saham. Permintaan saham yang meningkat akan menyebabkan nilai perusahaan meningkat.

Penelitian Suwardika dan Mustanda (2017) menunjukkan bahwa profitabilitas memiliki pengaruh positif dan signifikan terhadap nilai perusahaan. Hal ini sejalan dengan penelitian yang dilakukan oleh Nikmatussolichah et al. (2018), Chasanah dan Adhi (2017), Dhani dan Utama (2017), serta Putra dan Lestari (2016). Namun, hasil penelitian tersebut tidak sejalan dengan penelitian Thaib dan Dewantoro (2017) dan Tarima et al. (2016) yang menunjukkan bahwa profitabilitas tidak berpengaruh terhadap nilai perusahaan.

$\mathrm{Ha}_{1}$ : Profitabilitas berpengaruh positif terhadap nilai perusahaan

\section{Likuiditas}

Likuiditas adalah rasio yang mengukur kemampuan jangka pendek perusahaan untuk membayar kewajibannya dan untuk memenuhi kebutuhan uang tunai yang tidak terduga (Weygandt et al., 2019). Uttari dan Yadnya (2018) berpendapat bahwa perusahaan dengan likuiditas yang tinggi berarti perusahaan tersebut memiliki dana yang cukup untuk memenuhi kewajiban-kewajibannya, selain itu perusahaan juga mampu dalam memenuhi operasionalnya serta dalam pemberian dividen. Sehingga persepsi para investor akan semakin meningkat terhadap perusahaan tersebut dan diduga akan mengakibatkan harga saham perusahaan tersebut meningkat.

Penelitian Uttari dan Yadnya (2018) menunjukkan bahwa likuiditas memiliki pengaruh positif dan signifikan terhadap nilai perusahaan. Hal ini sejalan dengan penelitian yang dilakukan oleh Putra dan Lestari (2016), dan Suarnawa dan Abundanti (2016). Namun, hasil penelitian tersebut tidak sejalan dengan hasil penelitian Chasanah dan Adhi (2017) dan Nikmatussolichah et al. (2018) yang menunjukkan bahwa likuiditas tidak berpengaruh signifikan terhadap nilai perusahaan.

$\mathrm{Ha}_{2}$ : Likuiditas berpengaruh positif terhadap nilai perusahaan

\section{Pertumbuhan Perusahaan}

Pertumbuhan dapat diukur dengan pertumbuhan aset perusahaan. Pertumbuhan aset didefinisikan sebagai perubahan (tingkat pertumbuhan) tahunan dari total aset (Susanti, 2016). Menurut Suwardika dan Mustanda (2017), apabila perusahaan mampu meningkatkan aset, maka diperkirakan hasil operasional perusahaan juga akan meningkat sehingga semakin besar 
pula tingkat kepercayaan pihak luar terhadap suatu perusahaan. Investor yang memperoleh informasi mengenai pertumbuhan perusahaan yang diindikasikan melalui peningkatan total aset dari suatu perusahaan akan mendapat respon baik dari pasar, sehingga hal tersebut dapat meningkatkan harga saham ataupun mencerminkan nilai perusahaan yang meningkat.

Penelitian Syardiana et al. (2015) dan Nikmatussolichah et al. (2018), menunjukkan bahwa pertumbuhan perusahaan berpengaruh positif dan signifikan terhadap nilai perusahaan. Sedangkan, penelitian yang dilakukan Suwardika dan Mustanda (2017) menunjukkan bahwa pertumbuhan perusahaan memiliki pengaruh negatif namun signifikan terhadap nilai perusahaan. Namun, hasil penelitian Susanti (2016) dan Sudiani dan Darmayanti (2016) menunjukkan bahwa pertumbuhan perusahaan tidak berpengaruh terhadap nilai perusahaan.

$\mathrm{Ha}_{3}$ : Pertumbuhan perusahaan berpengaruh positif terhadap nilai

\section{Struktur Modal}

Struktur modal (Debt to Equity Ratio) yang rendah berarti perusahaan dalam mendanai asetnya cenderung menggunakan modal sendiri (internal financing) yang berasal dari laba ditahan dan modal saham daripada menggunakan utang (Novari dan Lestari, 2016). Rendahnya jumlah utang yang dimiliki perusahaan akan membuat risiko investor semakin kecil dan meningkatkan ekspektasi investor terhadap perusahaan tersebut.

Penelitian Suwardika dan Mustanda (2017) menunjukkan bahwa struktur modal memiliki pengaruh positif dan signifikan terhadap nilai perusahaan. Hal ini sejalan dengan penelitian yang dilakukan oleh Chasanah dan Adhi (2017), dan Hera dan Pinem (2017). Sedangkan, hasil penelitian Susanti (2016) menunjukkan bahwa struktur modal berpengaruh negatif namun signifikan terhadap nilai perusahaan. Namun, penelitian tersebut tidak sejalan dengan hasil penelitian Syardiana et al. (2015) dan Dhani dan Utama (2017) yang menunjukkan bahwa struktur modal tidak berpengaruh terhadap nilai perusahaan.

$\mathrm{Ha}_{4}$ : Struktur modal berpengaruh negatif terhadap nilai perusahaan.

\section{Model Penelitian}

Model penelitian yang digunakan dalam penelitian ini adalah sebagai berikut:

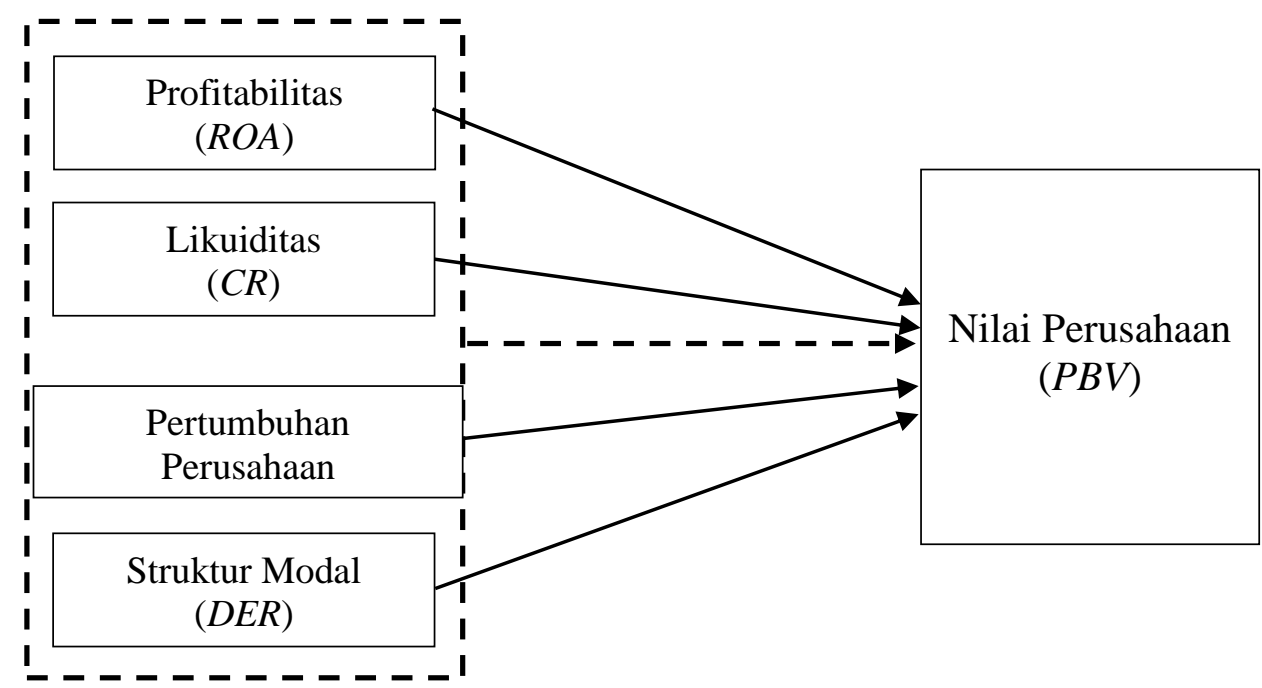

Gambar 2. Model Penelitian 


\section{METODE}

\section{Metode Penelitian}

Penelitian ini merupakan penelitian kuantitatif yang bertujuan untuk membuktikan adanya hubungan sebab akibat antar variabel yang mempengaruhi (independen) yaitu profitabilitas, likuiditas, pertumbuhan perusahaan, dan struktur modal dengan variabel yang dipengaruhi (dependen) yaitu nilai perusahaan. Penelitian ini menggunakan data sekunder berupa data laporan keuangan audited yang diterbitkan oleh perusahaan-perusahaan manufaktur sektor industri barang konsumsi yang terdaftar di Bursa Efek Indonesia (BEI) tahun 2016-2018 serta data saham yang diperoleh dari situs www.finance.yahoo.com.

\section{Operasional Variabel Penelitian}

\section{a) Variabel Dependen}

Nilai Perusahaan

Dalam penelitian ini, nilai perusahaan diproksikan dengan Price to Book Value (PBV) (Subramanyam, 2017):

$$
P B V=\frac{\text { Harga Pasar per lembar saham }}{\text { Nilai buku per lembar saham }}
$$

\section{b) Variabel Independen}

\section{Profitabilitas}

Return On Asset (ROA) adalah rasio yang dapat menunjukkan kemampuan perusahaan dalam mengelola aset perusahaan untuk menghasilkan laba (Weygandt et al., 2019):

$$
R O A=\frac{\text { Net Income }}{\text { Average Total Asset }}
$$

\section{Likuiditas}

Current Ratio $(C R)$ menunjukkan kemampuan perusahaan dalam memenuhi kewajiban jangka pendeknya melalui jumlah aset lancar yang dimiliki perusahaan (Weygandt et al., 2019):

$$
C R=\frac{\text { Current Assets }}{\text { Current Liabilities }}
$$

\section{Pertumbuhan Perusahaan}

Growth Ratio menunjukkan seberapa besar pertumbuhan perusahaan dengan membandingkan antara total aset periode sebelumnya dan total aset periode sekarang (Suwardika dan Mustanda, 2017): 


$$
\text { Growth }=\frac{\text { Total Asset }_{t}-\text { Total Asset }_{t-1}}{\text { Total Asset }_{t-1}}
$$

\section{Struktur Modal}

Debt to Equity Ratio (DER) menunjukkan seberapa besar utang perusahaan dibandingkan dengan ekuitas pemegang saham (Subramanyam, 2017):

$$
D E R=\frac{\text { Total Liabilities }}{\text { Total Stakeholder's Equity }}
$$

Penelitian ini menggunakan purposive sampling. dan menggunakan model regresi linier berganda untuk teknik analisis data. Berikut adalah rumus regresi linier berganda yang digunakan dalam penelitian ini adalah:

$$
P B V=\alpha+\beta_{1} R O A+\beta_{2} C R+\beta_{3} \text { Growth }-\beta_{4} D E R+e
$$

Keterangan:

$\begin{array}{ll}\text { PBV } & : \text { Price to Book Value } \\ \alpha & : \text { Konstanta } \\ \beta_{1,2,3,4} & : \text { Koefisien regresi } \\ \text { ROA } & : \text { Return on Asset } \\ \text { CR } & : \text { Current Ratio } \\ \text { Growth } & : \text { Pertumbuhan Perusahaan } \\ \text { DER } & : \text { Debt to Equity Ratio } \\ e & : \text { Kesalahan residual }\end{array}$

HASIL DAN PEMBAHASAN

Tabel 2. Hasil Statistik Deskriptif

\begin{tabular}{llrrrrr}
\hline & $\mathrm{N}$ & \multicolumn{1}{c}{ Range } & Minimum & Maximum & \multicolumn{1}{c}{ Mean } & Std. Deviation \\
\hline ROA & 45 & 1.09321 & .00940 & 1.10261 & .1703542 & .19600809 \\
CR & 45 & 8.03221 & .60563 & 8.63784 & 2.9816520 & 2.22509790 \\
GROWTH & 45 & .61810 & .00224 & .62034 & .1524778 & .14427711 \\
DER & 45 & 2.57125 & .08330 & 2.65455 & .7720389 & .65748912 \\
PBV & 45 & 68.82365 & .68491 & 69.50856 & 8.3788424 & 16.13462657 \\
Valid N & 45 & & & & & \\
(listwise) & & & & & & \\
\hline
\end{tabular}

Berdasarkan hasil statistik deskriptif pada Tabel 2, variabel $P B V$ memiliki nilai rata-rata (mean) sebesar 8,37884 dengan standar deviasi sebesar 16,13462657. Nilai rata-rata $P B V$ menunjukkan investor bersedia memberikan harga terhadap perusahaan sampel 8,38 kali lebih tinggi dibandingkan nilai bukunya. Variabel $R O A$ memiliki nilai rata-rata (mean) sebesar 0,1703542 dengan standar deviasi sebesar 0,19600809 . Nilai rata-rata $R O A$ menunjukkan bahwa rata-rata perusahaan sampel mampu memperoleh laba sebesar $17,04 \%$ dari 
penggunaan aset yang dimilikinya. Variabel $C R$ memiliki nilai rata-rata (mean) sebesar 2,9816520 dengan standar deviasi sebesar 2,22509790. Nilai rata-rata $C R$ menunjukkan bahwa rata-rata perusahaan sampel mampu melunasi 1 utang lancarnya dengan 2,9817 aset lancarnya. Variabel Growth memiliki nilai rata-rata (mean) sebesar 0,1524778 dengan standar deviasi sebesar 0,14427711. Nilai rata-rata Growth menunjukkan rata-rata total aset perusahaan sampel mengalami peningkatan sebesar $15,25 \%$ dibandingkan dengan periode sebelumnya. Variabel DER memiliki nilai rata-rata (mean) sebesar 0,7720389 dengan standar deviasi sebesar 0,65748912. Nilai rata-rata $D E R$ menunjukkan bahwa rata-rata perusahaan sampel lebih banyak menggunakan modal sendiri sebagai sumber pendanaan.

\section{Uji Asumsi Klasik}

Hasil uji asumsi klasik yang dilakukan menunjukkan bahwa penelitian ini lolos uji asumsi klasik. Pengujian normalitas dengan One Sample Kolmogrov-Smirnov menunjukkan nilai 2-tailed significant sebesar 0,917. Hasil uji multikolineritas menunjukkan bahwa variabel Return on Asset (ROA), Current Ratio (CR), Growth, dan Debt Equity Ratio (DER) memiliki nilai Tolerance yang lebih dari 0,10 dan nilai VIF yang lebih kecil dari 10, maka dapat disimpulkan bahwa tidak terjadi multikolonieritas antar variabel independen. Hasil uji autokorelasi menunjukkan nilai Durbin-Watson yang diperoleh (d) yaitu sebesar 2,263. Nilai Durbin-Watson (d) dari hasil uji terletak di antara du $<$ d $<4$-du $(1,7200<2,263<2,28)$ sehingga dapat disimpulkan bahwa tidak terjadi autokorelasi positif atau negatif. Hasil uji heteroskedastisitas dengan menggunakan scatter plot menunjukkan titik-titik menyebar secara acak dan tersebar baik di atas maupun di bawah angka 0 pada sumbu Y dan tidak membentuk pola tertentu yang teratur (bergelombang, melebar kemudian menyempit). Oleh karena itu, dapat disimpulkan bahwa tidak terjadi heteroskedastisitas pada model regresi.

\section{Uji Hipotesis}

\section{Uji Koefisien Determinasi}

Tabel 3. Hasil Uji Koefisien Determinasi

Model Summary ${ }^{\mathrm{b}}$

\begin{tabular}{crrrr}
\hline Model & R & R Square & $\begin{array}{c}\text { Adjusted R } \\
\text { Square }\end{array}$ & $\begin{array}{c}\text { Std. Error of } \\
\text { the Estimate }\end{array}$ \\
\hline 1 & $.872^{\mathrm{a}}$ & .760 & .736 & 8.29093428 \\
\hline
\end{tabular}

a. Predictors: (Constant), DER, GROWTH, ROA, CR

b. Dependent Variable: PBV

Berdasarkan Tabel 3, nilai koefisien korelasi (R) sebesar 0,872 yang menunjukkan korelasi atau hubungan sangat kuat antar variabel independen Return on Asset (ROA), Current Ratio (CR), Growth, dan Debt Equity Ratio (DER) dengan variabel dependen yaitu Price to Book Value $(P B V)$. Nilai Adjusted $R^{2}$ sebesar 0,736 yang menunjukkan bahwa Return on Asset (ROA), Current Ratio (CR), Growth, dan Debt Equity Ratio (DER) dapat menjelaskan Price to Book Value (PBV) sebesar 73,6\% dan sisanya yaitu 26,4\% dijelaskan oleh variabel lain yang tidak diteliti dalam penelitian ini.

\section{Uji Signifikansi Simultan (Uji Statistik F)}

Tabel 4. Hasil Uji Statistik F

\begin{tabular}{lrrrrrrr}
\multicolumn{8}{c}{ ANOVA $^{\mathrm{a}}$} \\
\hline Model & Sum of Squares & Df & Mean Square & F & Sig. \\
\hline 1 & Regression & 8704.768 & 4 & 2176.192 & 31.658 & $.000^{\mathrm{b}}$
\end{tabular}




\begin{tabular}{lrrr} 
Residual & 2749.584 & 40 & 68.740 \\
Total & 11454.352 & 44 & \\
\hline
\end{tabular}

a. Dependent Variable: PBV

b. Predictors: (Constant), DER, GROWTH, ROA, CR

Berdasarkan Tabel 4, nilai F hitung sebesar 31,658 dengan signifikansi 0,000 yang lebih kecil dari 0,05. Dengan demikian dapat disimpulkan bahwa Return on Asset (ROA), likuiditas yang diproksikan dengan Current Ratio $(C R)$, pertumbuhan yang diproksikan dengan Growth, dan struktur modal yang diproksikan dengan Debt to Equity Ratio (DER) secara serentak dan signifikan mempengaruhi nilai perusahaan yang diproksikan menggunakan Price to Book Value $(P B V)$.

Uji Signifikan Parameter Individual (Uji Statistik t)

Tabel 5. Hasil Uji Statistik t

Coefficients $^{\mathrm{a}}$

\begin{tabular}{|c|c|c|c|c|c|c|}
\hline & \multirow[t]{3}{*}{ Model } & \multicolumn{2}{|c|}{ Unstandardized Coefficients } & \multirow{3}{*}{$\begin{array}{c}\text { Standardized } \\
\text { Coefficients } \\
\text { Beta } \\
\end{array}$} & \multirow[t]{3}{*}{$\mathrm{t}$} & \multirow[t]{3}{*}{ Sig. } \\
\hline & & & & & & \\
\hline & & $\mathrm{B}$ & Std. Error & & & \\
\hline \multirow{5}{*}{1} & (Constant) & -12.039 & 4.625 & & -2.603 & .013 \\
\hline & $\mathrm{ROA}$ & 15.378 & 7.251 & .187 & 2.121 & .040 \\
\hline & $\mathrm{CR}$ & 1.900 & .846 & .262 & 2.247 & .030 \\
\hline & GROWTH & -39.979 & 9.159 & -.357 & -4.365 & .000 \\
\hline & DER & 23.609 & 3.115 & .962 & 7.580 & .000 \\
\hline
\end{tabular}

a. Dependent Variable: PBV

Berdasarkan Tabel 5, berikut adalah hasil persamaan regresi dalam penelitian ini:

$$
P B V=-12,039+15,378 R O A+1,900 C R-39,979 G R O W T H+23,609 D E R
$$

Keterangan:

$\begin{array}{ll}\text { PBV } & : \text { Price to Book Value } \\ \text { ROA } & : \text { Return on Asset } \\ \text { CR } & : \text { Current Ratio } \\ \text { GROWTH } & : \text { Pertumbuhan Perusahaan } \\ \text { DER } & : \text { Debt to Equity Ratio }\end{array}$

Untuk variabel Return on Asset (ROA) menunjukkan hasil uji statistik t sebesar 2,121 dengan tingkat signifikansi yang kurang dari 0,05 yaitu 0,040. Berdasarkan hasil tersebut dapat disimpulkan bahwa Ha 1 diterima yang berarti bahwa profitabilitas berpengaruh positif signifikan terhadap nilai perusahaan. Hal ini sejalan dengan penelitian Suwardika dan Mustanda (2017), Chasanah dan Adhi (2017), dan Putra dan Lestari (2016) yaitu profitabilitas berpengaruh positif dan signifikan terhadap nilai perusahaan.

Variabel Current Ratio $(C R)$ memiliki hasil uji statistik t sebesar 2,247 dengan tingkat signifikansi yang kurang dari 0,05 yaitu 0,030. Berdasarkan hasil tersebut dapat disimpulkan bahwa $\mathrm{Ha}_{2}$ diterima yang berarti bahwa likuiditas berpengaruh positif signifikan terhadap nilai perusahaan. Hal ini sejalan dengan penelitian yang dilakukan oleh Uttari dan Yadnya 
(2018), Putra dan Lestari (2016), dan Suarnawa dan Abundanti (2016) menunjukkan bahwa likuiditas berpengaruh positif dan signifikan terhadap nilai perusahaan.

Variabel Growth dengan hasil uji statistik t -4,365 dengan tingkat signifikansi yang kurang dari 0,05 yaitu 0,000 sehingga dapat disimpulkan bahwa pertumbuhan perusahaan berpengaruh negatif signifikan terhadap nilai perusahaan. Hal ini menunjukkan bahwa $\mathrm{Ha}_{3}$ ditolak. Walaupun pertumbuhan perusahaan berpengaruh signifikan terhadap nilai perusahaan tetapi pengaruh tersebut bersifat negatif bukan positif. Hasil penelitian ini menunjukkan ratarata sampel mengalami pertumbuhan aset sebesar 15,25\%. Dari 45 observasi terdapat 40 observasi atau sebesar $88,89 \%$ mengalami peningkatan penjualan dengan rata-rata $9,30 \%$. Dapat dilihat bahwa rata-rata peningkatan penjualan lebih kecil dari peningkatan asetnya. Hal ini menunjukkan bahwa peningkatan asetnya tidak efektif untuk meningkatkan penjualan perusahaan dikarenakan mayoritas perusahaan melakukan penambahan aset bukan berupa aset produktif yang mempengaruhi penjualan. Dari 45 observasi terdapat 23 observasi atau sebesar $51,11 \%$ perusahaan melakukan penambahan aset berupa tanah, inventaris perusahaan, peralatan kantor dan kendaraan, bukan untuk meningkatkan produktivitasnya sehingga peningkatan penjualan tidak selaras dengan peningkatan asetnya. Dari 23 observasi tersebut mengalami rata-rata peningkatan aset sebesar $16,51 \%$ dan rata-rata peningkatan penjualan sebesar $8,13 \%$. Hal ini membuat laba bersih meningkat dengan rata-rata sebesar $12,63 \%$. Laba yang meningkat membuat retained earning juga meningkat dengan rata-rata 6,68\%. Dari retained earning yang meningkat membuat pembagian dividennya meningkat dengan rata-rata $9,25 \%$. Namun rata-rata peningkatan harga saham hanya sebesar $7,55 \%$ sehingga rata-rata $P B V$ mengalami penurunan sebesar 5,55\%. Dapat disimpulkan bahwa peningkatan aset tidak membuat $P B V$ mengalami kenaikan karena peningkatan aset tersebut bukan peningkatan aset produktif. Hasil penelitian ini sejalan dengan penelitian yang dilakukan Suwardika dan Mustanda (2017) menunjukkan bahwa pertumbuhan perusahaan memiliki pengaruh negatif tetapi signifikan terhadap nilai perusahaan.

Variabel Debt to Equity Ratio (DER) memiliki hasil uji statistik t sebesar 7,580 dengan tingkat signifikansi yang kurang dari 0,05 yaitu 0,000 sehingga dapat disimpulkan bahwa struktur modal berpengaruh positif signifikan terhadap nilai perusahaan. Hal ini menunjukkan bahwa $\mathrm{Ha}_{4}$ ditolak. Walaupun struktur modal berpengaruh signifikan terhadap nilai perusahaan tetapi pengaruh tersebut bersifat positif bukan negatif. Menurut hasil penelitian ini $D E R$ menunjukkan arah positif. Berdasarkan data yang ada, dari 45 observasi terdapat 35 observasi atau sebesar 77,77\% mengalami kenaikan utang dengan rata-rata 27,71\%. Dari 35 observasi terdapat 24 observasi atau sebesar $68,57 \%$ peningkatan utangnya didominasi oleh peningkatan utang usaha dimana utang usaha tidak memiliki beban bunga. Utang usaha ini digunakan perusahaan sampel untuk pembelian bahan baku, bahan kemasan, bahan pembantu dan barang jadi untuk dijual sehingga penjualannya meningkat. Dari 24 observasi terdapat 22 observasi atau sebesar $91,67 \%$ penjualannya meningkat dengan rata-rata 9,28\%. Penjualan yang meningkat dengan beban yang efisien dapat menghasilkan laba yang tinggi, hal ini dapat dilihat dari 22 observasi terdapat 19 observasi atau sebesar 86,36\% labanya meningkat. Laba yang tinggi membuat retained earning perusahaan tinggi sehingga potensi perusahaan membagikan dividen tinggi, hal ini dapat dibuktikan dari 19 observasi terdapat 16 observasi atau sebesar $84,21 \%$ yang mengalami peningkatan retained earning dan dari 16 observasi terdapat 11 observasi atau sebesar 68,75\% pembagian dividennya meningkat. Perusahaan memiliki banyak utang tetapi tetap banyak membagikan dividen. Hal tersebut akan menarik minat investor sehingga harga sahamnya pun meningkat. Dari 11 observasi terdapat 6 observasi atau sebesar 54,54\% mengalami peningkatan harga saham. Harga saham yang meningkat membuat $P B V$ juga meningkat dengan rata-rata peningkatan 46,01\%. Hal ini sejalan dengan hasil penelitian Suwardika dan Mustanda (2017), Chasanah dan Adhi (2017), 
dan Hera dan Pinem (2017) menunjukkan bahwa struktur modal berpengaruh positif dan signifikan terhadap nilai perusahaan.

\section{SIMPULAN}

Berdasarkan hasil penelitian yang dilakukan dapat disimpulkan bahwa Return on Asset $(R O A)$, likuiditas yang diproksikan dengan Current Ratio $(C R)$, pertumbuhan yang diproksikan dengan Growth, dan struktur modal yang diproksikan dengan Debt to Equity Ratio (DER) secara serentak dan signifikan mempengaruhi nilai perusahaan yang diproksikan menggunakan Price to Book Value (PBV). Secara parsial profitabilitas, likuiditas, dan struktur modal memiliki pengaruh positif signifikan terhadap nilai perusahaan. Sedangkan pertumbuhan perusahaan memiliki pengaruh negatif signifikan terhadap nilai perusahaan. Implikasi dalam penelitian ini bagi perusahaan, harus memperhatikan Return On Assets (ROA) dan Current Ratio (CR) untuk meningkatkan nilai perusahaannya. Perusahaan harus efisien dalam menggunakan aset untuk menghasilkan laba dan berhati-hati dalam menjaga likuiditasnya agar memiliki nilai perusahaan yang tinggi. Sedangkan bagi investor, jika ingin memilih perusahaan dengan Price to Book Value ( $P B V$ ) yang tinggi maka investor disarankan untuk memilih perusahaan yang memiliki Return On Assets (ROA) dan Current Ratio (CR) yang tinggi.

\section{DAFTAR PUSTAKA}

Bursa Efek Indonesia. (2018). Data Kapitalisasi Pasar Industri Tahun 2016-2019. Diakses di idx.co.id: https://www.idx.co.id/data-pasar/laporan-statistik/statistik/ pada tanggal 31 Oktober 2019.

Chasanah, A., \& Adhi, D. (2017). Profitabilitas, Struktur Modal dan Likuiditas Pengaruhnya Terhadap Nilai Perusahaan Pada Perusahaan Real Estate yang Listed di BEI Tahun 2012-2015. Fokus Ekonomi: Jurnal Ilmiah Ekonomi, 12(2).

Dhani, I., \& Utama, A. (2017). Pengaruh Pertumbuhan Perusahaan, Struktur Modal, dan Profitabilitas Terhadap Nilai Perusahaan. Jurnal Riset Akuntansi dan Bisnis Airlangga, 2(1), 135-148.

Haryadi, E. (2016). Pengaruh Size Perusahaan, Keputusan Pendanaan, Profitabilitas dan Keputusan Investasi Terhadap Nilai Perusahaan. Jurnal Akuntansi, 3(2).

Hera, M., \& Pinem, D. (2017). Pengaruh Likuiditas dan Struktur Modal Terhadap Nilai Perusahaan Dengan Profitabilitas Sebagai Variabel Intervening Pada Perusahaan yang Terdaftar Di Bursa Efek Indonesia. EQUITY, 20(1).

Khoirunnisa, et al. (2018). Pengaruh Struktur Modal Terhadap Nilai Perusahaan Pada Perusahaan Tekstil dan Garmen. Journal of Business Management Education, 3(2).

Kohar, A., \& Akramunnas, A. (2017). Pengaruh Struktur Modal dan Kebijakan Dividen Terhadap Nilai Perusahaan. Assets: Jurnal Ekonomi, Manajemen dan Akuntansi, 7(1).

Mudjijah, S., et al. (2019). Pengaruh Kinerja Keuangan dan Struktur Modal Terhadap Nilai Perusahaan yang Dimoderasi Variabel Ukuran Perusahaan. Jurnal Akuntansi dan Keuangan, 8(1). 
Nikmatussolichah, et al. (2018). Pengaruh Profitabilitas, Likuiditas dan Pertumbuhan Perusahaan Terhadap Kebijakan Dividen dan Nilai Perusahaan Manufaktur yang Terdaftar Di BEI Tahun 2015-2017. E-Jurnal Ilmiah Riset Akuntansi, 7(9).

Novari, P. \& Lestari, P. (2016). Pengaruh Ukuran Perusahaan, Leverage, dan Profitabilitas Terhadap Nilai Perusahaan Pada Sektor Properti dan Real Estate. E-Jurnal Manajemen Unud, 5(9).

Nugraha, A., et al. (2018). Pengaruh Pertumbuhan Perusahaan dan Profitabilitas Terhadap Nilai Perusahaan Pada Perusahaan Sektor Property yang Terdaftar Di Bursa Efek Indonesia Periode 2012-2016. Bisnis dan Iptek, 11(2).

Putra, A. \& Lestari, P. (2016). Pengaruh Kebijakan Dividen, Likuiditas, Profitabilitas dan Ukuran Perusahaan Terhadap Nilai Perusahaan. E-Jurnal Manajemen Unud, 5(7).

Putri, J. (2016). Pengaruh Struktur Modal Terhadap Nilai Perusahaan Pada Perusahaan Manufaktur Go Publik (Studi Kasus Sektor Makanan dan Minuman). JOM FISIP, 3(2).

Sindonews.com. Tahun ini PT Sekar Laut Tbk Bidik Pertumbuhan Penjualan 15 Persen. Retrieved from jatim.sindonews.com: https://jatim.sindonews.com/read/11653/1/tahunini-pt-sekar-laut-tbk-bidik-pertumbuhan-penjualan-15-persen-1560838012 diakses pada 18 June 2019

Sindonews.com. Sekar Laut Berencana Tingkatkan Kapasitas Produksi Sambal. Retrieved from jatim.sindonews.com: https://daerah.sindonews.com/read/1313225/23/sekar-lautberencana-tingkatkan-kapasitas-produksi-sambal-1528621306 diakses pada 18 June 2019

Suarnawa, I. \& Abundanti, N. (2016). Profitabilitas dan Likuiditas Sebagai Prediktor Kebijakan Dividen dan Nilai Perusahaan Pada Perusahaan Manufaktur di BEI. E-Jurnal Manajemen Unud, 5(9), 5585-5611.

Subramanyam, K., (2017). Financial Statement Analysis (11th Edition). Jakarta: Salemba Empat.

Sudiani, N. \& Darmayanti, N. (2016). Pengaruh Profitabilitas, Likuiditas, Pertumbuhan, dan Investment Opportunity Set Terhadap Nilai Perusahaan. E-Jurnal Manajemen Unud, 5(7), 4545-4547.

Susanti, N. (2016). Pengaruh Struktur Modal, Pertumbuhan Perusahaan, Profitabilitas, dan Kebijakan Dividen Terhadap Nilai Perusahaan Studi Pada Emiten Sektor Manufaktur Di BEI. Jurnal Reviu Akuntansi dan Keuangan (JRAK), 7(2).

Suwardika, I. \& Mustanda, I. (2017). Pengaruh Leverage, Ukuran Perusahaan, Pertumbuhan Perusahaan, dan Profitabilitas Terhadap Nilai Perusahaan Pada Perusahaan Properti. EJurnal Manajemen Unud, 6(3), 1248-1277.

Syardiana, G., et al. (2015). Pengaruh Investment Opportunity Set, Struktur Modal, Perumbuhan Perusahaan dan Return On Asset Terhadap Nilai Perusahaan. Akuntabilitas, 8(1). 
Tarima, G., et al. (2016). Pengaruh Profitabilitas, Keputusan Investasi dan Keputusan Pendanaan Terhadap Nilai Perusahaan Farmasi yang Terdaftar Di BEI Periode 20112014. Jurnal Berkala Ilmiah Efisiensi, 16(4).

Thaib, I., \& Dewantoro, A. (2017). Pengaruh Profitabilitas dan Likuiditas Terhadap Nilai Perusahaan dengan Struktur Modal sebagai Variabel Intervening. Jurnal Riset Perbankan Manajemen dan Akuntansi, 1(1).

Uttari, I. \& Yadnya, I. (2018). Pengaruh Likuiditas dan Struktur Modal Terhadap Kebijakan Dividen dan Nilai Perusahaan. E-Jurnal Manajemen Unud, 7(6).

Weygandt, et al. (2019). Financial Accounting with International Financial Reporting Standards, 4th Edition. USA: John Wiley \& Sons, Inc. 